\title{
Алгоритм исследования прооксидантной системы организма с целью выбора патогенетической фармакотерапии
}

\author{
Бакулина Л.С. ${ }^{1}$, Плужников Н.Н. ${ }^{2}$, Исаев А.В. ${ }^{1,3}$ \\ ${ }^{1}$ ФГБОУ ВО Воронежский государственный медицинский университет им. Н.Н.Бурденко \\ Минздава России, Воронеж \\ ${ }^{2}$ НИИЦ (Медико-биологической защиты) ГНИИИВМ МО РФ, С-Петербург \\ ${ }^{3}$ ФГБОУ ВО «Воронежский государственный университет». Воронеж
}

Поступила в редакцию 13.08.2018 г.

DOI: https://doi.org/10.17308/sorpchrom.2018.18/605

Регуляторная функция свободнорадикальных процессов в обеспечении жизнедеятельности клетки и их присутствие в качестве промежуточного этапа в ряде жизненно важных ферментативных реакций, определяют актуальность исследований, посвященных оценке продукции и инактивации свободных радикалов. Изучение прооксидантной и антиоксидантной систем, интенсивности свободнорадикального окисления (СРО) позволяет решить многие проблемы, как-то: выявление динамики активности патологического процесса, прогноза того или иного патологического состояния, а также выбора возможных путей фармакологической коррекции про- и антиоксидантного баланса при воспалительных заболеваниях.

Инициацию и поддержание оксидативного стресса, а также нарушение структуры и гибель клетки ряд авторов связывают с повреждением клеточных мембран и перекисным окислением их липидов. Создание алгоритма исследования показателей активности прооксидантной системы с использованием современных спектрофотометрических и хроматографических методов, позволяет последовательно «шаг за шагом» определить и оценить данные показатели.

Ключевые слова: свободные радикалы, прооксиданты, антиоксидантная система, гидроперекиси, свободнорадикальное окисление, спектрофотометрические методы, хроматографические методы.

\section{Prooxidant body system study algorithm with the view of pathogenetic pharmacotherapy option}

\author{
Bakulina L.S. ${ }^{1}$, Pluzhnikov N.N. ${ }^{2}$, IsaevA.V. ${ }^{1,3}$ \\ ${ }^{I}$ Voronezh State Medical University. N.N. Burdenko of the Ministry of Health of Russia, Voronezh \\ ${ }^{2}$ Research Center of Medico-Biological Defense, St. Petersburg \\ ${ }^{3}$ Voronezh State University, Voronezh
}

Regulatory function of free radical processes in cell vital activity supply/provision and their presence as interim step in a number of vital enzymatic reactions determine the topicality of studies devoted to the assessment of free radicals production and inactivation. The study of prooxidant and antioxidant systems and the free radical oxidation intensity makes it possible to solve a lot of problems such as dynamics detection of pathological process activity, the prognosis of one or another pathological condition, the choice of possible ways of prooxidant and antioxidant balance pharmacological correction in inflammatory diseases as well.

Initiation and maintenance of oxidative stress as well as structure impairment and cell death are sometimes considered associated with cell membrane impairment and their lipids peroxidation. The devel- 
opment of prooxidant system activity rates study algorithm through up-to-date spectrophotometric and chromatographic methods makes it possible to define and assess step-by-step the rates obtained.

Keywords: free radicals, prooxidants, antioxidant system, hydroperoxides, free radical oxidation, spectrophotometric methods, chromatographic methods.

\section{Введение}

Согласно современным представлениям, в основе воспалительных процессов в организме лежат повреждения клеточных и субклеточных структур свободными радикалами, с которыми связаны многие микропроцессы жизнедеятельности организма. Интенсивность процессов пероксидации регулируется многоступенчатой антиоксидантной (антирадикальной) системой, отдельные звенья которой воздействуют на различные этапы образования перекисных соединений и продуктов их метаболизма (прооксидантов). Несоответствие продукции прооксидантов может развиваться как при чрезмерном образовании свободных кислородных радикалов, так и в случае истощения антирадикальных систем, даже при стационарном уровне генерации биологических окислителей. Регуляторная функция свободнорадикальных процессов в обеспечении жизнедеятельности и их присутствие в качестве промежуточного этапа в ряде жизненно важных ферментативных реакций, определяют актуальность исследований, посвященных оценке продукции и инактивации свободных радикалов. В аэробных биологических системах в той или иной мере всегда выполняются условия для поддержания процессов свободнорадикального окисления (СРО) [1]. При этом образуется целый ряд биологических окислителей, обладающих высокой химической активностью и способных модифицировать структуру любой биомолекулы. Поддержание редокс (red/ox)-потенциала внутренней среды организма на стационарном уровне осуществляется при участии систем антиоксидантной защиты. В этой связи чрезвычайно важно выяснение соотношения между прооксидантными и антиоксидантными системами. Изменение этих соотношений может привести к избыточной активации СРО и фатальным изменениям в биологических системах.

Существует значительное число методов оценки интенсивности свободнорадикальных процессов, однако их широкое применение в клинической и исследовательской практике ограничено [2]. Это связано с недостаточной стандартизацией методов выявления и интерпретации результатов, отсутствием выработанных подходов к оценке той или иной системы восстановления кислорода или определению антиоксидантной активности фармакологических препаратов. Кроме того, трудности могут быть связаны с двоякой ролью свободных радикалов $(\mathrm{CP})$ в биологических системах: наряду с альтерирующим действием, они могут выполнять функцию вторичных мессенджеров.

Изучение прооксидантной и антиоксидантной систем, а также взаимоотношений между ними, может быть направлено на решение целого ряда задач:

1. выявление динамики интенсивности СРО (по сравнению с ее обычным уровнем) как маркера активности патологического процесса;

2. определение активности защитных функций клеток (в частности, лейкоцитов и макрофагов), в том числе хроматографическими методами;

3. оценка прогноза того или иного патологического состояния;

4. выяснение особенностей реакции организма на то или иное воздействие.

Разделение прооксидантной системы на составляющие важно для понимания ее роли в клеточном метаболизме и сигнализации. Однако, в практических исследованиях подавляющее большинство методов позволяет лишь выявить факт образования того или иного радикала, определить его примерное количество, выявить субстрат, на который воздействуют СР и провести количественную оценку продуктов 
такого взаимодействия. Многие биохимические реакции и клеточные процессы, в которых образуются активные формы кислорода, известны и хорошо изучены. Существует несколько подходов к изучению СРО: морфологическое исследование структуры органелл, повреждение которых предполагается при той или иной патологии; изучение активности ферментных систем, ответственных за образование СР; индикация самих СР с использованием хромогенных или флуоресцирующих субстратов; определение продуктов взаимодействия СР с биосубстратами; выявление результатов активации СРО (в большинстве случаев регистрируют апоптоз и некроз клеток). Инициацию и поддержание оксидативного стресса, а также нарушение структуры и гибель клетки многие авторы связывают с повреждением клеточных мембран и перекисным окислением их липидов (Рис.1 Структура типичной эукариотической плазматической мембраны) [3]. При этом считают, что действию прооксидантов наиболее подвержены полиеновые кислоты (арахидоновая, линолевая, линоленовая), входящие в состав фосфолипидов и содержащие несколько двойных связей [4]. Однако при сохранении стабильности липидного бислоя мембран свободнорадикальное окисление фосфолипидов не несет для клетки таких фатальных последствий [5], которые возникают при гидролизе фосфолипидов и лабилизации свободных жирных кислот.

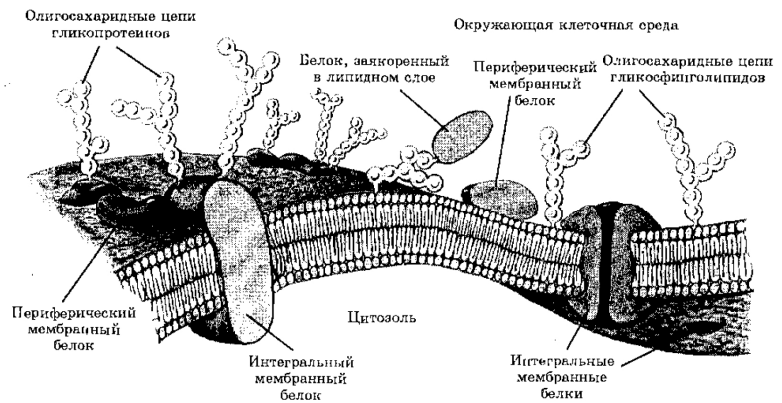

Рис.1 Структура типичной эукариотической плазматической мембраны [3]

Все тесты для оценки прооксидантной системы можно разделить на несколько групп, представленных на рис 2. Классификация методов основана как на химическом принципе, отражающем вид выявляемых метаболитов, так и на физиологическом подходе, в большей степени базирующемся на анализе реакций биологических систем на СРО.

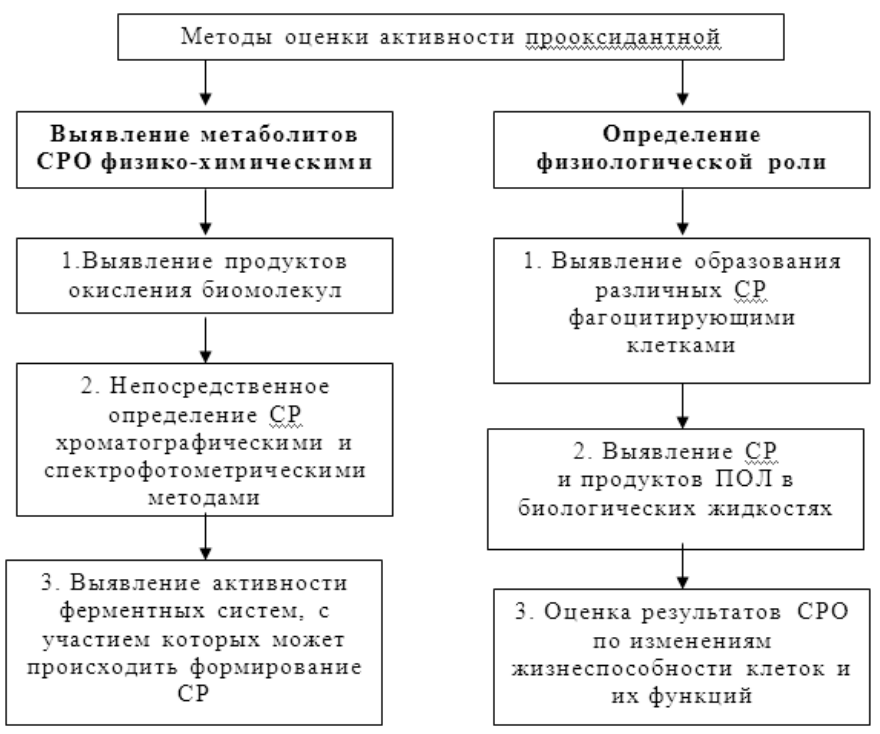

Рис.2. Алгоритм методов оценки активности прооксидантной системы 
Химическая классификация тестов. Первая группа методов основана на выявлении продуктов окисления биомолекул.

1. Определение неспецифических продуктов взаимодействия СР с липидами и свободными жирными кислотами: малоновый диальдегид (МДА):<smiles>O=CCC=O</smiles>

4-гидроксигексаналь, 4-гидрокси-2-ноненаль, конъюгированные диены (ДК), конъюгированные триены. К явным преимуществам этих методов относится простота и доступность, возможность использования их в качестве скрининговых в клинических лабораториях. В то же время постулируется их низкая чувствительность, что можно отнести к недостаткам.

Поэтому наряду с вышеперечисленными компонентами ряд авторов считает необходимым определять при взаимодействии СР с липидами содержание гидроперекисей жирных кислот. Ими было установлено закономерное увеличение содержания гидроперекисей жирных кислот при острых и хронических воспалительных процессах как непосредственно в органе-очаге, так и в сыворотке крови. Выявлена корреляция между количеством МДА, ДК у беременных и выраженностью гипоксии у новорожденных, причем эти показатели перекисного окисления липидов (ПОЛ) имеют прогностическое значение. Необходимо отметить, что накапливающиеся в тканях продукты пероксидации липидов являются мутагенами и обладают выраженной цитотоксичиостью: подавляют активность гликолиза [7] и окислительного фосфорилирования, ингибируют синтез белка и нуклеиновых кислот, окисляют белковые SH-группы [8], ингибируют различные цитозольные и мембраносвязанные ферменты. Все это также подчеркивает важность их определения. Вместе с тем следует учитывать, что МДА образуется не только в результате окислительной деградации ДК жирных кислот, но и в процессе образования простагландинов. Поэтому представляется обоснованным определение содержания специфических продуктов реакций СР с белками и ДНК.

2. Выявление специфических продуктов взаимодействия СР с ДНК и белками по количеству окисленных (нитрозированных) азотистых оснований и аминокислотных остатков, в частности, тирозина, фенилаланина и нитрозогемоглобина. Основным маркером СР-модификации ДНК считается 8-оксо-7,8-дигидрокси-2дезоксигуанозин (8-oxodG) [9]. Важно отметить, что уровень 8-oxodG увеличивается при целом ряде патологических состояний, в частности, в ткани легких и лимфоцитах при раке легкого, в моче онкологических больных [12]. В ряде исследований продукты окислительной модификации ДНК рассматриваются как начальное звено химического канцерогенеза.

Вторую группу методов составляют способы непосредственного определения свободных радикалов. Некоторые соединения, т.н. «сенсоры активных форм кислорода» (Dane Py, HO-1889NH), взаимодействуют с синглетным кислородом или супероксиданион-радикалом в растительных клетках и под действием УФ-излучения (280-360 нм) дают флуоресценцию, клеточная локализация которой определяется при помощи метода конфокальной лазерной сканирующей микроскопии [13].

Для непосредственного выявления свободных радикалов применяют метод хемилюминесценции, возникающей при взаимодействии некоторых веществ, в частности люминола, люцигенина и пенициллина $\mathrm{G}[14,15]$, с активными формами кислорода. Отмечена определенная специфичность люминофоров относительно СР, вступающих в реакцию. Так, люминол в большей степени взаимодействует с пероксидом водорода и пероксинитритом, тогда как люциргенин - с супероксидным ани- 
он-радикалом. Несмотря на то, что люциргенин, представляя собой red/ox пару, сам может выступать как источник супероксидного радикала [17], такой путь превращения люцигенина практически не реализуется, и люцигенин-зависимая люминесценция является одним из наиболее чувствительных и специфичных методов выявления супероксидного радикала.

При использовании методов хемилюминесценции разные авторы оценивают различные параметры свечения. Большинство исследователей определяют спонтанную и стимулированную хемилюминесценцию. При оценке стимулированной хемилюминесценции определяют амплитуду быстрой вспышки (характеризующую уровень гидроперекисей липидов), амплитуду медленной вспышки (характеризующую содержание биоокислителей) и время достижения максимумов медленной и быстрой вспышки, которое отражает состояние антиоксидантных систем организма. Показатель светосуммы за первую минуту коррелирует с интенсивностью свободнорадикального окисления, а за первые 4 минуты, как наиболее информативный интегральный показатель, - отражает квантовый выход произошедших в модельной системе свободнорадикальных реакций. По индексу хемилюминесценции, отношению максимума интенсивности и интенсивности свечения через 4 мин после инициации, оценивают потенциал системы антиоксидантной защиты. В других исследованиях применяют иные характеристики хемилюминесценции: время достижения максимума и его значение, угол наклона кривой, площадь под кривой при наблюдении в течение 90 мин. При этом изменение времени реагирования на стимул и максимальное значение дыхательной вспышки расценивают как модификацию резервных метаболических возможностей клеток [19].

Третью группу методов оценки прооксидантных систем составляют способы определения активности ферментных систем, с участием которых может происходить формирование свободных радикалов:

a) Система «ксантиндегидрогеназа - ксантиноксидаза». При окислении свободных сульфгидрильных групп в дисульфидные снижается дегидрогеназная активность ферментного комплекса (в качестве акцептора водорода выступает $\mathrm{NAD}^{+}$) (Рис. 3 Окислительно-восстановительный кофермент никотинамидадениндинуклеотид) и повышается его оксидазная активность с образованием активных форм кислорода [20].

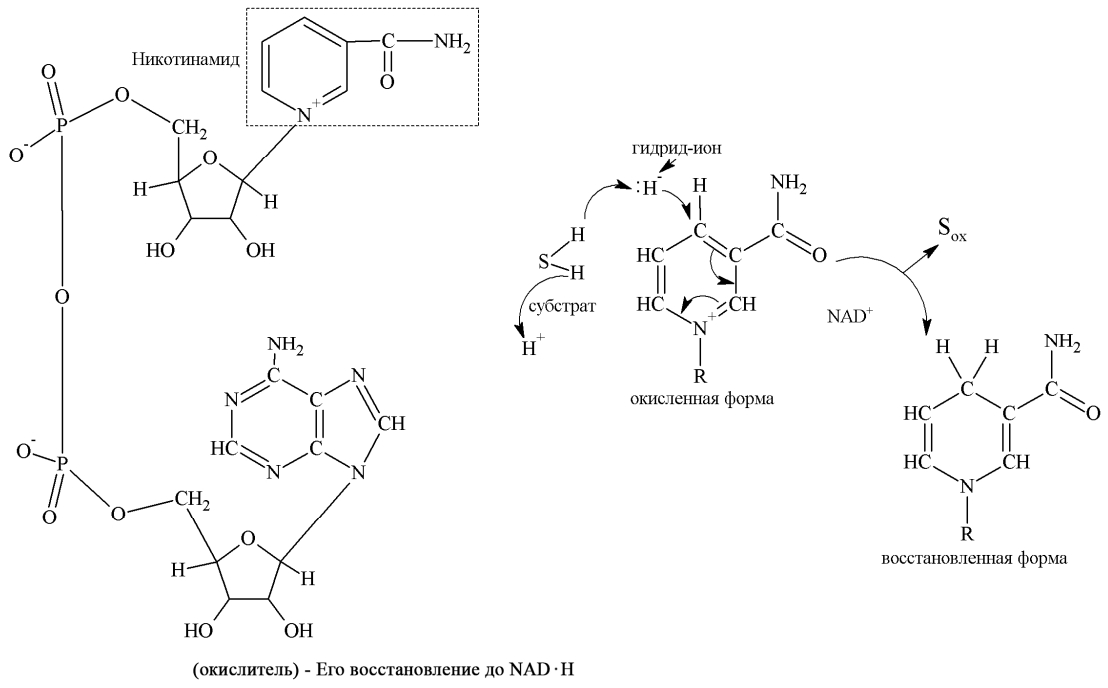

Рис. 3. Окислительно-восстановительный кофермент никотинамидадениндинуклеотид (NAD) 
б) Система NO-синтетазы, которая в НАДФ-зависимой реакции образует оксид азота (II) (NO). Выделяют несколько изоформ фермента (nNOS, eNOS и iNOS), которые отличаются по локализации, механизмам активации и выполняемой функции.

в) Миелопероксидаза - гемсодержащий фермент, экспрессируемый активированными фагоцитами, который катализирует образование гипохлорита из хлориданиона и перекиси водорода. Гипохлорит, наряду с сильнейшими окислительными свойствами, обладает способностью вступать в реакцию Осипова с образованием гидроксильного радикала. Эти радикалы, обладающие выраженным бактерицидным действием, в физиологических условиях направлены на окисление чужеродного белка и некоторых токсических соединений [21].

г) К ферментным системам, продуцирующим АФК, относится и циклооксигеназа.

д) Аскорбатоксидаза катализирует окисление аскорбиновой кислоты с образованием аскорбатрадикала. Ее определение осуществляют по изменению концентрации восстановленного аскорбата спектрофотометрически и методом высокоэффективной жидкостной хроматографии (ВЭЖХ).

Заметный вклад по использованию сорбентов для выделения, разделения, анализа антиоксидантов и других физиологически активных веществ внесен советскими и российскими хроматографистами. Исследования московских, ленинградских, харьковских, воронежских, саратовских хроматографистов $[22,23,24,25,26$, $27,28]$ показали перспективность использования высокопористых сетчатых полиэлектролитов (как неионогенных, так и с различными полярными и ионогенными фиксированными группами). В качестве примера следует привести способ выделения и разделения аминокислот, меланоидинов и т-РНК из биомассы различных дрожжевых производств с использованием бимодального сорбента Стиросорб МХДЭ х100 [23, 24, 25].

Сорбент, имеющий в матрице достаточное количество гидрофобных «карманов», способен связывать крупные органические молекулы. Связывание т-РНК Стиросорбом проходит в несколько стадий и включает первоначально формирование монослоев в сорбенте за счет дисперсионных взаимодействий при $\mathrm{pH}=1,5$. Так как молекулы т-РНК имеют сложную пространственную структуру, то после формирования монослоев вне мезопор могут находиться и спаренные спиралевидные участки, и однонитевые петли, и концевые нуклеозидные фрагменты.

Образование полислоев наиболее вероятно связано с образованием водородных связей между пуриновыми (аденин) фрагментами «акцепторного плеча» т-РНК первого адсорбционного слоя [3] и пиримидиновым основанием (урацил) «дополнительного плеча» или D-петли последующего слоя [24]. Наряду с этим, образование дополнительных Н-связей между монослоями является вероятным за счет взаимодействия цитозиновых групп акцепторной цепи первого слоя и гуаниновых остатков «дополнительного плеча» или D-петли второго адсорбционного слоя.

Образующиеся ассоциаты двух полинуклеотидных цепей комплементарны и обладают достаточной стабильностью, зависящей от температуры. При пониженных температурах (ниже $15^{\circ} \mathrm{C}$ ) формирование полислоев т-РНК предпочтительнее, что свидетельствует об образовании полярных (ориентационных связей) $[24,25,26,27$, 28]. Элюирование т-РНК из фазы сорбента осуществляют 0,5М раствором хлорида натрия, а меланоидинов - 1М раствором гидроксида натрия. При сорбции т-РНК, меланоидинов, аминокислот макросетчатыми полимерами имеет место явление, которое получило в современной химии название «организованные среды» [27]. Такие среды, образованные дифильными молекулами или ионами в сорбенте микрогетеро- 
генны и двухфазны на наноуровне, хотя однофазны и гомогенны в макромасштабе. Различие во взаимодействии сорбата и сорбента выступает как многоточечное и многофункциональное (электростатическое, дисперсионное, индукционное, ориентационное, донорно-акцепторное), а в случае образования пересыщенных растворов аминокислот в ионитах позволяет исключить стадию специальной элюции ряда аминокислот из Стиросорба и процесс упаривания [25, 28]

е) В настоящее время известно более сотни изоформ микросомальных монооксигеназ, в том числе и цитохрома Р-450 [29], представляющих собой мультиферментные мембраносвязанные комплексы, основное предназначение которых состоит в детоксикации липофильных ксенобиотиков посредством гидроксилирования [30, $31,32]$.

Физиологическая классификация методов. Физиологическая классификация основана на группировке методов относительно определенных популяций клеток и биологических сред, в которых выявляются продукты СРО, а также на оценке биологических результатов СРО применительно к клеточному и надклеточному уровням организации. Знание этих особенностей имеет принципиальное значение для оценки биологической роли СР.

Первую группу методов составляет выявление образования различных свободных радикалов фагоцитирующими клетками. Наиболее распространенными способами оценки образования СР фагоцитами являются методы хемилюминесценции и флуоресценции с применением различных стимуляторов.

Вторую группу составляют методы выявления метаболитов перекисного окисления липидов в биологических жидкостях. Для определения продуктов СРО в биологических жидкостях, в частности в цельной крови, сыворотке и плазме крови, используют так же метод хемилюминесценции [2].

Третью группу методов составляют способы оценки развития не самого СРО, а его результатов. Для оценки жизнеспособности клеток, в особенности фагоцитов, используют гистологическую окраску нативных препаратов с трепановым синим (окрашивающиеся клетки считаются нежизнеспособными). Для оценки апоптотических клеток применяют методы выявления фрагментации ДНК в экстрактах клеточных ядер: TUNEL-анализ [33] или проточную цитометрию с применением пропидия иодида $\left(\mathrm{C}_{3} \mathrm{H}_{7} \mathrm{OJ}\right)$ [34]. Кроме того, выявление апоптоза, некроза и дистрофических изменений клеточных структур проводят с использованием классических гистологических методик и электронной микроскопии.

Таким образом, представленный алгоритм исследования прооксидантной системы организма является наиболее полным, отражая динамику течения воспалительных процессов при различной локализации и позволяет выбрать рациональную патогенетическую фармакотерапию. Липидный бислой формирует матрикс биологических мембран, а белки (некоторые из них являются гликопротеинами) ассоциированы с ним различными способами. Интегральные мембранные белки локализованы внутри бислоя и обычно пронизывают оба пласта. Гидрофобные аминокислотные остатки трансмембранных сегментов этих белков участвуют в ван-дер-ваальсовых взаимодействиях с гидрофобными хвостами липидных молекул. Периферические мембранные белки слабо ассоциированы с поверхностью мембраны через ионные взаимодействия и водородные связи либо с полярными головками липидных молекул, либо с интегральными мембранными белками. «Заякоренные» в липидах мембранные белки связаны с мембраной за счет ковалентных связей с несколькими типами липидных молекул. 


\section{Список литературы}

1. Плужников Н.Н., Чиж С.М., Юзвинкевич Л.С. // Актуальные проблемы и перспективы развития военной медицины: науч. тр. НИИЦ (МБЗ) ГНИИИВМ МО РФ. СПб, 2000. Т. 2. С. 193-223.

2. Арутюнян А.В., Дубинина Е.Е., Зыбина Н.Н. Методы оценки свободнорадикального окисления и антиоксидантной системы организма. СПб. 2000. $103 \mathrm{c}$.

3. Жеребцов Н.А., Попова Т.Н., Артюхов В.Г. Биохимия. Учебник. Воронеж. Изд-во ВГУ. 2002. 696 с.

4. Плужников Н.Н. // Актуальные проблемы и перспективы развития военной медицины: науч. тр. НИИЦ (МБЗ) ГНИИИВМ МО РФ. СПб. 2003. Т. 4. С. 123139.

5. Геннис Р. Биомембраны: молекулярная структура и функции: пер. с англ. М. Мир. $1997.624 \mathrm{c}$.

6. Floyd R.A., Hensley K. // Neurobio. Aging. 2002. Vol. 23. pp. 795-807.

7. Владимиров Ю.А., Арчаков А.М.. Перекисное окисление липидов в биологических мембранах. М. Наука. 1972. $167 \mathrm{c}$.

8. Lewis S.E., Wills E.D. // Biochem. Pharmacol. 1962. Vol. 11.P. 901.

9. Cadet J.M., Bellon S., Berger M. //J. Biol. Chem. 2002. Vol. 383. No 6. pp. 933-943.

10. Floyd R.A. // Anal.Biochem. 1990. Vol. 188. pp. $155-158$.

11. Inoue M. // Jpn. J. Cancer Res. 1998. Vol. 89. pp. 691-695.

12. Tagesson C. // Euгоp. J. Cancer. 1995. No 6. pp. 934-940.

13. Hideg E. // Plant. Cell. Physiol. 2002. Vol. 43. No 10. pp. 1154-1164.

14. Rost M., Karge E., Klinger W. // J. Biolumin. Chemilumin. 1998. Vol. 13. No 6. pp. 355-363.

15. Shen H.M., Yang C.F., Ong C.N. // Intern. J. Cancer. 1999. Vol. 81. No 5. pp. 820828.

16. Faulkner K., Fridovich I. // Free Radic. Biol. Med. 1993. Vol 15. No 4. pp. 447-451.

17. Liochev S.I., Fridovich I. // Arch. Biochem. Biophys. 1997. Vol. 337. No 1. pp. 115-120.
18. Кратнов А.Е.// Клин. лаб. диагностика. 2002. №6. C 6-13.

19. Куртасова Л.М. // Клин. лаб. диагностика. 2003. №2. С 16-18.

20. Waud W.R., Rajagopalan K.V. // Arch. Biochem. Biophys. 1976. Vol. 172. No 2. pp. 365-379.

21. But P.G. // lzv. Akad. Nauk: Ser. Biol. 2002. No 3. pp. 266-270.

22. Самсонов Г.К., Меленевский А.Т. Сорбционные и хроматографические методы физико-химической биотехологии. Л. Наука. 1986. 229c.

23. Даванков В. А. Навратил Дж., Уолтон $\mathrm{X}$. Лигандообменная хроматография. М. Мир. 1990. 294 c.

24. Селеменев В.Ф., Котова Д.Л., Орос Г.Ю., Загородний А.А. Хроматография низкого давления физиологически активных веществ В кн. «100 лет хроматографии». М. Наука. 2003. С. 546-569.

25. Селеменев В.Ф. Дис. ... Д-ра хим. наук. Воронеж. 1993. 594 с.

26. Темиров Ю.П., Шостенко Ю.В., Шеин А.Т. // Хим.-фармачевт. журнал. 1978. Т.12. № 10. C.114-117.

27. Штыков С.Н. Люминесцентный анализ в организованных средах /B кн. «Люминесцентный анализ». 2015. С. 121155.

28. Селеменев В.Ф., Рудаков О.Б., Славинская Г.И., Дроздова Н.В. Пигменты пищевых производств. М. ДеЛи принт. 2008. $246 \mathrm{c}$.

29. Арчаков А.И., Карузина И.И. // Вести. АМН СССР. 1988. № 1. С 14-23.

30. Бакибаев А.А. // Хим.-фармач. журн. 1995. № 3. C. 3-14.

31. Мишин В.М. Множественные формы цитохрома Р-450. Новосибирск. 1985. 182 с.

32. Саприн А.Н. // Успехи биол. химии. 1991. T. 32. C. 146-175.

33. Gavrieli Y., Sherman Y., Ben-Sasson S.A. // J. Cell. Biol. 1992. Vol. 119. No 3. pp. 493-501.

34. Nicoletti I.A., Migliorati G., Pagliacci M.C. // J. Immunol. Meth. 1991. Vol. 139. No 2. pp. 271-279. 


\section{References}

1. Pluzhnikov N.N., CHizh S.M., YUzvinkevich L.S. // Aktual'nye problemy i perspektivy razvitiya voennoj mediciny: nauch. tr. NIIC (MBZ) GNIIIVM MO RF, SPb, 2000, Vol. 2, pp. 193-223.

2. Arutyunyan A.V., Dubinina E.E., Zybina N.N. Metody ocenki svobodnoradikal'nogo okisleniya i antioksidantnoj sistemy organizma, $\mathrm{SPb}, 2000,103 \mathrm{p}$.

3. ZHerebcov N.A., Popova T.N., Artyuhov V.G. Biohimiya: Uchebnik,Voronezh, Izd-vo VGU, 2002, 696 p.

4. N.N. Pluzhnikov [ i dr.], Aktual'nye problemy $i$ perspektivy razvitiya voennoj mediciny: nauch. tr. NIIC (MBZ) GNIIIVM MO R, SPb., 2003, Vol. 4, pp. 123-139.

5. Gennis R. Biomembrany: molekulyarnaya struktura i funkcii: per. s angl., M., Mir, 1997, 624 p.

6. Floyd R.A., Hensley K., Neurobio. Aging., 2002, Vol 23, pp. 795-807.

7. Vladimirov YU.A. Perekisnoe okislenie lipidov $\mathrm{v}$ biologicheskih membranah, M., Nauka, 1972, 167 p.

8. Lewis S.E., Wills E.D., Biochem. Pharmacol., 1962, Vol. 11, pp. 901.

9. Cadet J.M., Bellon S., Berger M., J. Biol. Chem., 2002,Vol. 383, No 6, pp. 933-943.

10. Floyd R.A., Anal.Biochem., 1990, Vol 188, pp. 155-158.

11. M. Inoue, Jpn. J. Cancer Res., 1998, Vol. 89, pp. 691-695.

12. Tagesson C., Euгоp. J. Cancer, 1995, No 6, pp. 934-940.

13. Hideg E., Plant. Cell. Physiol., 2002, Vol. 43, No 10, pp. 1154-1164.

14. Rost M., Karge E., Klinger W., J. Biolumin. Chemilumin., 1998, Vol. 13, No 6, pp. 355-363.

15. Shen H.M., Yang C.F., Ong C.N., Intern. J. Cancer, 1999, Vol. 81, No 5, pp. 820828.

16. Faulkner K., Fridovich I., Free Radic. Biol. Med., 1993, Vol 15, No 4, pp. 447-451.

17. Liochev S.I., Fridovich I., Arch. Biochem. Biophys., 1997, Vol. 337, No 1, pp. 115-120.

Бакулина Лариса Сергеевна - д.м.н., профессор кафедры оториноларингологии, Воронежский государственный медицинский университет им. Н.Н. Бурденко Минздрава России, Воронеж
18. Kratnov A.E., Klin. lab. Diagnostika, 2002, No 6, pp. 6-13.

19. Kurtasova L.M., Klin. lab. Diagnostika, 2003, No 2, pp. 16-18.

20. Waud W.R., Rajagopalan K.V., Arch. Biochem. Biophys., 1976, Vol. 172, No 2, pp. 365-379.

21. But P.G., lzv. Akad. Nauk: Ser. Biol., 2002, No 3, pp. 266-270.

22. Samsonov G.K., Melenevskij A.T., Sorbtsionnye i khromatograficheskie metody fiziko-himicheskoj biotekhologii, L., Nauka, 1986, $229 \mathrm{p}$.

23. Davankov V.A. Navratil Dzh., Uolton H. Ligandoobmennaya hromatografiya, M., Mir, 1990, $294 \mathrm{p}$.

24. Selemenev V.F., Kotova D.L., Oros G.YU., Zagorodnij A.A., V kn. «100 let hromatografii», M., Nauka, 2003, pp. 546-569.

25. Selemenev V.F. Dis. ... d-ra him. nauk., Voronezh, 1993, 594 p.

26. Temirov YU.P., SHostenko YU.V., SHein A.T., Khim.-farmacevt. Zhurnal, 1978, Vol. 12, No 10, pp. 114-117.

27. Shtykov S.N. Lyuminescentnyj analiz v organizovannyh sredah, $\mathrm{V} \quad \mathrm{kn}$. «Lyuminescentnyj analiz», Pod red. G. I. Romanovskoj, 2015, pp. 121-155.

28. Selemenev V.F., Rudakov O.B., Slavinskaya G.I., Drozdova N.V. Pigmenty pischevyh proizvodstv, M., DeLi print, 2008, $246 \mathrm{p}$.

29. Archakov A.I., Karuzina I.I., Vesti. AMN SSSR, 1988, No 1, pp. 14-23.

30. Bakibaev A.A. et al., Khim.-farmac. zhurn., 1995, No 3, pp. 3-14.

31. Mishin V.M. Mnozhestvennye formy citohroma R-450, Novosibirsk, 1985, 182 p.

32. Saprin A.N., Uspekhi biol. Himii, 1991, Vol. 32, pp. 146-175.

33. Gavrieli Y., Sherman Y., Ben-Sasson S.A., J. Cell. Biol., 1992, Vol. 119, No 3, pp. 493-501.

34. Nicoletti I.A., Migliorati G., Pagliacci M.C., J. Immunol. Meth., 1991, Vol. 139, No 2, pp. 271-279.

Bakulina Larisa. S. - M.D., DSci., Full Professor, Dept.of Otorhinolaryngology, Voronezh State Medical University. N.N. Burdenko of the Ministry of Health of Russia, Voronezh 
Плужников Николай Николаевич - д.м.н., профессор, НИИЦ (Медико-биологической защиты) ГНИИИВМ МО РФ; С-Петербург

Исаев Андрей Викторович - к.м.Н., ассистент кафедры оториноларингологии Воронежский государственный медицинский университет им. Н.Н. Бурденко Минздрава России; доцент кафедры клинической фармакологии, ФГБОУ ВО «Воронежский государственный университет», Воронеж
Pluzhnikov Nikolay N. - M.D., DSci., Full Professor, Research Center of Medico-Biological Defense, St. Petersburg

Isaev Andrey V. - M.D., Assistant Professor, Dept. of Otorhinolaryngology, Voronezh State Medical University. N.N. Burdenko of the Ministry of Health of Russia; Associate Professor of Clinical Pharmacology Department at Voronezh State University, Voronezh 